\section{Acute psychosis in elderly: do not forget the CASPR2 spectrum as a possible cause}

\author{
André Ricardo Merkle, Marco Antônio Machado \\ Schlindwein, Letícia Caroline Breis and Marcus Vinícius \\ Magno Gonçalves* \\ Department of Medicine, University of the Region of Joinville, Santa Catarina, Joinville, 89202-207, Brazil
}

Received: 28 March, 2020

Accepted: 29 May, 2020

Published: 30 May, 2020

*Corresponding author: Marcus Vinícius Magno Gonçalves, MD, PhD, Department of Medicine, University of the Region of Joinville, Rua Ministro Calogenas, 439, Bucarein, Joinville, Santa Catarina, 89202-207 Brazil, E-mail: mvmpesquisa@gmail.com; marcusribeirao@yahoo.com.br https://www.peertechz.com

Check for updates
Antibodies against contactin-associated protein 2 (CASPR2), a protein associated with the Voltage-Gated Potassium Channel Complex (VGKC) [1], represent an emerging cause of some old neurological manifestations; such as Morvan's and Isaacs' syndromes, as well as a variety of phenotypes encompassing limbic encephalitis, neuropathic pain, late onset epilepsy and dysautonomia [2,3].

Although the prevalence of anti-neuronal surface antibodies and their impact on clinical practice is not wellestablished [4-7], they represent an important etiology of autoimmune encephalitis and a curable cause of dementia and acute psychosis [8-10].

In a study by Baumgartner, et al. $34 \%$ of the patients with autoimmune encephalitis were initially admitted to the psychiatry department. In addition, psychiatry disturbances represent the second most common presentation of autoimmune encephalitis after seizures [11].

When it comes to anti-CASPR2 psychiatric phenotypes, symptoms tend to present in a progressive manner (5-7 months); mostly with no fluctuations, and a tumor is present in $19 \%$ of the patients $[2,10]$. It affects mostly elderly man (Figure 1) $[2,12]$ and clinical presentation ranges from cognitive decline, sleep disorders, depressive mood, global amnesia especially when associated with anti-Leucine-rich, glioma inactivated 1 (anti-LGI1) antibodies - and psychotic episodes ${ }^{12}$. Other symptoms, such as seizures, peripheral nerve symptoms and dysautonomia may appear later in the disease, possibly being misdiagnosed as dementia or psychiatric disease [2].

It is important to highlight that most of the patients with anti-CASPR2 have either normal MRI image or hippocampal atrophy, which holds and association with anti-LGI1 antibodies; and therefore the diagnosis may be challenging when facing a case with this suspected etiology [13].

\section{Who is the anti-CASPR2 + psychiatric patient ?}

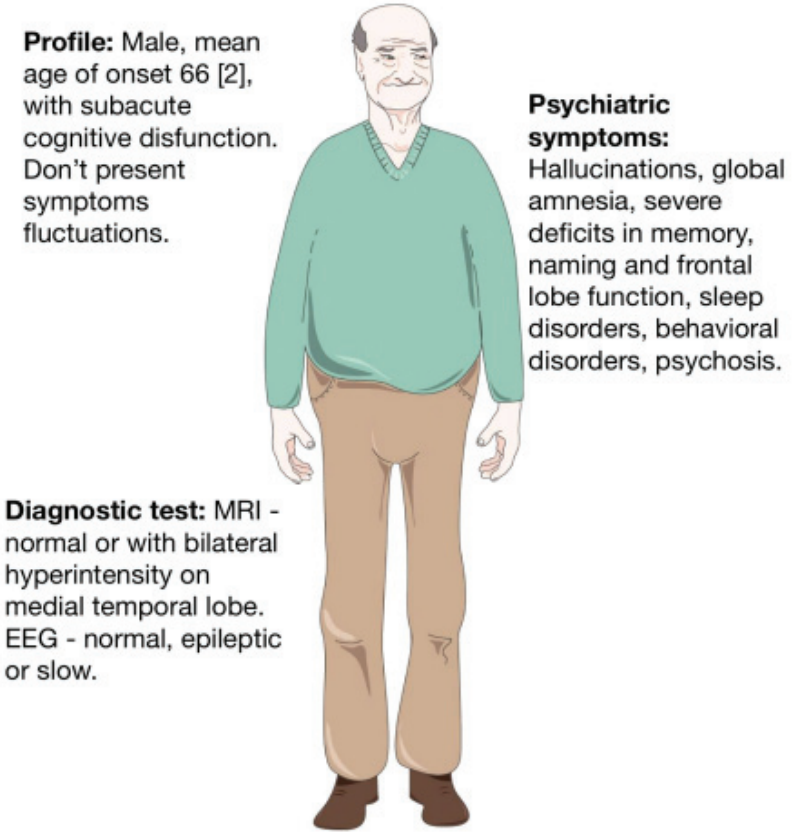

Figure 1: We summarized the profile of the patient that usually present with the anti-CASPR2 psychiatric phenotypes. Elderly man image acquired at http://smart. servier.com/. 
In conclusion, antibodies against CASPR2 should be remembered as a cause of cognitive imbalance or psychosis, especially in elderly men, even with a normal MRI image. Also, if a tumor is not yet known, it is important to make a screening. Finally, anti-CASPR2 disorders respond well to immunotherapy, but may acquire a poor prognosis, especially when treatment is delayed due a misdiagnosis [12].

\section{Author's contributions}

Performed data acquisition and data analysis as well helping with the writing in the text: André Ricardo Merkle, Letícia Caroline Breis, Marco Antônio Machado Schlindwein.

Made substantial contributions to conception and design of the study, as well as provided technical support: Marcus Vinicius Magno Gonçalves MD PhD.

\section{References}

1. Saint-Martin, M, Joubert, B, Pellier-Monnin, V, Pascual, O, Noraz, et al. (2018) Contactin-associated protein-like 2, a protein of the neurexin family involved in several human diseases. Eur J Neurosci 48: 1906-1923. Link: https://bit. ly/3gzivl3

2. van Sonderen A, Ariño $H$, Petit-Pedrol $M$, Leypoldt $F$, Körtvélyessy $P$, et al. (2016) The clinical spectrum of Caspr2 antibody-associated disease. Neurology 87: 521-528. Link: https://bit.ly/3eq5mPy

3. Binks SNM, Klein CJ, Waters P, Pittock SJ, Irani SR (2017) LGI1, CASPR2 and related antibodies: a molecular evolution of the phenotypes $\mathrm{J}$ Neurol Neurosurg Psychiatry 89.

4. Schou M, Sæther S, Borowski K, Teegen B, Kondziella D, et al. (2016) Prevalence of serum anti-neuronal autoantibodies in patients admitted to acute psychiatric care. Psychol Med 46: 3303-3313. Link: https://bit ly/3gJ1mMi
5. Gaughran F, Lally J, Beck K, McCormack R, Gardner-Sood P, et al. (2018) Brain-relevant antibodies in first-episode psychosis: A matched case-control study. Psychol Med 48: 1257-1263. Link: https://bit.ly/2TPBqF0

6. Lennox BR, Palmer-Cooper EC, Pollak T, Hainsworth J, Marks J, et al. (2017) Prevalence and clinical characteristics of serum neuronal cell surface antibodies in first-episode psychosis: a case-control study. Lancet Psychiatry 4: 42-48.0 Link: https://bit.ly/3der9cN

7. Scott J, Gillis D, Ryan A, Hargovan H, Gundarpi N, et al. (2018) The prevalence and treatment outcomes of antineuronal antibody-positive patients admitted with first episode of psychosis. BJPsych Open 4: 69-74. Link: https://bit ly/2TPjzh4

8. Pollak T,Lennox B (2018) Time for a change of practice: The real-world value of testing for neuronal autoantibodies in acute first-episode psychosis. BJPsych Open 4: 262-264. Link: https://bit.ly/3dciV5e

9. McKeon A (2016) Autoimmune Encephalopathies and Dementias. Continuum 22: 538-558. Link: https://bit.ly/3caWuMh

10. Schou MB, Sæther SG, Drange OK, Krane-Gartisern K, Reitan SK, Kristian O, et al. (2018) The significance of anti-neuronal antibodies for acute psychiatric disorders: a retrospective case-controlled study. BMC Neurosci 19: 68. Link: https://bit.ly/2BeWeiH

11. Baumgartner A, Rauer S, Hottenrott T, Leypoldt F, Ufer F, et al. (2019) Admission diagnoses of patients later diagnosed with autoimmune encephalitis. J Neurol 266: 124-132. Link: https://bit.ly/3cbrlmE

12. Prüss H, Lennox BR (2016) Emerging psychiatric syndromes associated with antivoltage-gated potassium channel complex antibodies. J Neurol Neurosurg Psychiatry 87: 1242-1247. Link: https://bit.ly/2M6P5Dh

13. Heine J, Prüss H, Bartsch T, Ploner CJ, Paul F, et al. (2015) Imaging of autoimmune encephalitis--Relevance for clinical practice and hippocampal function. Neuroscience 309: 68-83. Link: https://bit.ly/3cfnfiP

\section{Discover a bigger Impact and Visibility of your article publication with}

Peertechz Publications

\section{Highlights}

* Signatory publisher of ORCID

* Signatory Publisher of DORA (San Francisco Declaration on Research Assessment)

- Articles archived in worlds' renowned service providers such as Portico, CNKI, AGRIS, TDNet, Base (Bielefeld University Library), CrossRef, Scilit, J-Gate etc.

* Journals indexed in ICMJE, SHERPA/ROMEO, Google Scholar etc.

- OAI-PMH (Open Archives Initiative Protocol for Metadata Harvesting)

* Dedicated Editorial Board for every journa

* Accurate and rapid peer-review process

* Increased citations of published articles through promotions

* Reduced timeline for article publication

Submit your articles and experience a new surge in publication services (https://www.peertechz.com/submission).

Peertechz journals wishes everlasting success in your every endeavours.

Copyright: @ 2020 Merkle AR, et al. This is an open-access article distributed under the terms of the Creative Commons Attribution License, which permits unrestricted use distribution, and reproduction in any medium, provided the original author and source are credited.

Citation: Merkle AR, Machado Schlindwein MA, Breis LC, Magno Gonçalves MV (2020) Acute psychosis in elderly: do not forget the CASPR2 spectrum as a possible cause. J Neurol Neurol Sci Disord 6(1): 008-009. DOI: https://dx.doi.org/10.17352/jnnsd.000037 